\title{
Where are all the science librarians?
}

By Susan M. Vazakas

Chemistry, Physics, and Astronomy Bibliographer Boston University and Camille Clark Wallin

Librarian

LABAT-ANDERSON, Inc *

\section{What you can do to combat the science librarian shortage.}

I $\mathrm{t}$ is generally acknowledged that there is a shortage of librarians with backgrounds or training in the science and technology fields. ${ }^{1,2}$ Anne Beaubien, the President of the Association of College and Research Libraries (ACRL) chose "recruitment" as a theme for 1991-92, with an emphasis on hard-to-find specialties such as science. How can those of us already in the profession do our part to help increase the numbers of current and future librarians who will practice in science, medicine, or technology? Recruitment efforts should be intensified, and can take place at the levels of undergraduate student, library school student, library professional, and professionals outside librarianship.

\section{Recruiting at the undergraduate level}

A largely untapped reservoir of library science recruits can be found among the undergraduate population. According to a 1988 survey, only $29 \%$ of some 1,547 library school students had chosen a career in the library field prior to getting their bachelor degrees. ${ }^{3}$ Academic librarians are in a unique position to reach many students who have not yet declared their majors or have no idea about what they would like to do after they graduate. At the reference desk, during library tours, and during formal and informal bibliographicinstruction, there are opportunities to talk about what we do and what steps are required to become a librarian. Sci-tech librarians who teach subject-specific library resource seminars and classes should mention either to the students or to the instructor that they would be happy to discuss opportunities in science librarianship with any student who might be interested.

\section{The personal approach}

Because most colleges and universities across the country do not have library schools, independent study courses done cooperatively between the department and an academic librarian provide a rare opportunity for undergraduates who have an interest in libraries to get some exposure to the field under the tutelage of a professional librarian. To this end, science librarians should take a particular interest in student workers who are science majors. They may be student assistants in the academic library, summer interns in a corporate library, or pages and library aides in the public library. Speak to them one-on-one about librarianship. Since they are already working in a library, they will be receptive to what you have to say. Along this same vein, special librarians at science and technology firms in cities without library schools can advertise for student help or summer co-ops and internships through science departments at nearby campuses.

A 1979 survey at the George Peabody College for Teachers School of Library Science found that $87 \%$ of the respondents had previous library experience, such as working as a student assistant, and $34 \%$ said

-Under contract to the Environmental Monitoring Systems Laboratory Library of the U.S. Environmental Protection Agency 
theywere influencedintheircareerchoice bylibrarians. ${ }^{4}$ Clearly, this personal approach is an effective means to reach the undergraduate student.

\section{In the library schools}

If someone who is studying for an MLS has not yet given much thought to specializing in a particular type of service or type of library, a class in an area the student finds interesting might tip the scales for that person. Accordingly, if one's library school has a good course in the literature of science and technology, one might become interested enough in the area to want to learn more about it and perhaps become a science librarian. This assumes that two conditions are present, however: that the library school has a sci-tech course, and that the professor of the course has personal experience with the literature and is able to present it clearly and in a way that is interesting. This is certainly not always the case. One of the authors had a sci-tech professor with a background in religion. He assigned only one project for the entire semester: each student was to choose a subdiscipline in science or technology, such as botany or pharmacy, and deliver a presentation on the tools one could use to find information in that area. The students ended up attempting to teach themselves how to use specialized bodies of literature with no guidance whatsoever from the professor. They learned little, and much worse, became frustrated by the science and technology literature.

\section{Courses in science/technology literature}

Unfortunately, statistics on how many accredited library schools in the country offer a course on the literature of science and technology that is separate from the regular reference course are not available. ${ }^{5}$ Some schools do not offer such a course at all. Other programs have a sci-tech course in the curriculum, but have only unqualified or underqualified people to teach it. This should not be surprising; if only $5 \%$ of all MLS degrees are taken by people with a science background, it is logical to assume that an even smaller number of library school professors have such a background.

At the other end of the spectrum, however, are a handful of programs that offer specialization or joint degrees in library science and a scientific field. Southem Connecticut State University's School of Library Science and Instructional Technology offers a dual master's program-the graduate emerges with an MLS as well as an M.S. in chemistry. The program at Indiana University in Bloomington, Indiana, provides an MLS with a specialization in chemistry, requiring a bachelor's degree in chemistry or its equivalent for admittance. Graduates of Indiana's program currently hold positions at Dow
Chemical Company, Union Carbide, Bell Laboratories, the National Institutes of Health, the University of Indiana library system, and Chemical Abstracts Service, to name just a few. Catholic University of America in Washington, D.C., offers a choice: a joint M.S./MLS degree in library science and biology, or a specialization in biomedical information services. Awareness of such programs by members of the profession and sci-tech librarians in particular is essential. Support such programs by informing science undergrads and others about them, and by requesting brochures to post on science department bulletin boards around campus.

\section{Improving library school science education}

While these types of programs are invaluable for providing specialized scientific backgrounds for future librarians, they are few and far between. If the administrators of a given library school program plan to offer a sci-tech course, they should attempt to hire someone who is familiar with the literature. Hiring a librarian from a science, medical, or technology library, either academic or corporate, as a

\section{Much of the science phobia prevalent among librarians without any science background is simply the lack of experience with the material.}

visiting or adjunct professor would seem to be a sensible and reasonably uncomplicated way to provide a much needed course for library science students.

In addition, if library science programs were to offer a sci-tech course at least once a year, greater numbers of students would have the opportunity to be exposed to such literature, and therefore the degree of "science phobia" among these potential future sci-tech librarians would be lessened. Much of the science phobia prevalent among librarians without any science background is simply the lack of experience with the material, and a solid, interesting course would do wonders toward dispelling such impressions.

Like those recruiting science librarians at the undergraduate level, library science professors should make a point of explaining the more practical considerations of science librarianship: that science librarians are very marketable and in much demand; that there are terrific internships available such as the one at the National Library of Medicine; 


\section{Our Library of Congress Classification Cumulative Schedules and Indexes offer many advantages over the competition:}

- All LC Additions \& Changes are integrated with the basic LC schedules into one book, so that the cataloger only has to look in one place to find the most up-to-date classification numbers.

- Supplements are published quarterly, after the issuance of each LC Additions \& Changes List. The competition only supplements their schedules annually.

- Each schedule is attractively bound in a sturdy three-ring loose-leaf binder, with each major section divided by tabs for easy access.

\section{Compiled by Larry $D$. Dershem}

Class H Subclasses HM-HX Social Sciences

Class H Subclasses H-HJ Social Sciences: Economics

Class Z Bibliography and Library Science

Class J Political Science

Also available are the schedules and indexes for Class K Subclass KF (Law of the United States, 2v., \$110); Subclass K (Law, General \$60); Subclass KD (Law of the United Kingdom and Ireland, \$75); Subclass KE (Law of Canada, \$75); Class KDZ, KG-KH (Law of the Americas, \$85); Class KJV-KJW (Law of France, \$85); Class KK-KKC (Law of Germany, \$95); and Class KJ-KKZ (Law of Europe, \$95). Estimated annual cost of updating: $\$ 52.50$ per volume

The process of cataloging library materials is time consuming and expensive. Why not give your technical services department the edge by purchasing our time saving LC Classification Cumulative Schedules and Indexes today!

To place an order, call or write:

\section{Fred B. Rothman \& Co.}

10368 West Centennial Road / Littleton, CO 80127 (800) 457-1986 
and that corporate libraries in engineering firms and biotechnology firms, to name only two, offer attractive salaries to those with such background or training. In addition, government megaprojects like the Human Genome Project and national laboratories such as Los Alamos are desperate for information specialists, and have even allotted portions of their multi-billion-dollar budgets for the hiring of such persons.

\section{Recruiting within the profession}

This level would perhaps be the hardest at which to recruit science librarians. Usually by the time one has obtained a professional position, s/he has chosen, at least initially, an area of librarianship such as academic librarianship, or a specialty such as social science, in which to work or concentrate. In addition, people without a science background can be intimidated by the thought of having to get a handle on imposing sets like Chemical Abstracts. This is certainly understandable; one of the authors, who hasn't a scrap of experience with business literature, breaks out in hives when she even walks past items like Standard and Poor's Register of Corporations, Directors, and Executives. However, someone who has experience using the science and technology literature, and enthusiasm for doing so, can explain the ins and outs of the major tools clearly, and make it interesting, to his or her colleagues. This kind of explanation can be accomplished through anything from an informal memo to an in-service training presentation, such as that held by one of the authors when asked by her colleagues to explain the arrangement of chemical compounds in some of the reference sources.

\section{Reference questions-more than just science}

In academic sciencelibraries, the reference questions are not all about designing solid rocket boosters or isolating plant alkaloids. Science, medicine, and technology are the underpinnings of much of today's society, and have become a factor in almost every societal situation that arises. As a result, the variety of information required by students and researchers covers the entire spectrum of subjects. There are class projects about conservation of the rain forests, degradation of the ozone layer, the ethics of organ transplantation, biodegradable materials, and patenting microorganisms. A science librarian might get a legal question about recent legislation conceming pesticides, a policy question about the funding of the Superconducting Supercollider, or a business question about the conflicts of interest between university scientists and the biotechnology industry. Recently a student with an art history major and a chemistry minor requested a computer search about the weathering of marble-she was applying for an internship at Boston's Museum of Fine Arts! The variety of questions is boundless, and librarians with backgrounds in history, archaeology, public policy, law, or the social sciences are extremely valuable as science librarians because they are able to provide more complete answers to multidisciplinary inquiries.

With the current staffing shortages and the effort it takes to hire and train a professional librarian, an article whose intent appears to be to spirit away everyone's best people to the land of science librarianship might not be appreciated. The recruiting efforts the authors discuss in this article are aimed at college science majors, librarians who are just starting their professional careers, and professionals who are interested in a change of specialization or simply wish to expand their horizons. As science librarians, it falls within our professional responsibility to publicize opportunities in science librarianship for these groups and educate those interested about what we do. The "Each One Reach One" campaign developed by the ALA Office for Library Personnel Resounces ${ }^{7}$ works especially well in the realm of science librarianship and should be encouraged.

\section{Other professional recruiting steps}

Small steps within the professional milieu that simply provide exposure to science libraries and what science librarians do can also be very helpful in the recruiting effort. For example, within academic library systems, job rotations to branch libraries whose collections are science- or technology-oriented would acquaint or reacquaint nonscience colleagues with the literature and the clientele from those fields. What about "exposure" opportunities at library conferences? Open houses and programs sponsored by the science and technology sections of both ALA and SI_A are excellent opportunities to acquaint one with science librarianship and the scientific literature. For example, ACRL's Science and Technology Section is planning a preconference in New Orleans in 1993 on training nonscience librarians to do science reference.

\section{Outside the profession}

So how do we reach the potential librarian who is working in a different field altogether? In a survey conducted by Pearson and $\mathrm{Webb}^{8}$, over 70 percent of library school students worked full-time in other fields before deciding to become librarians; 63 percent of these "made an outright career change into librarianship." They are the science journalist who is browsing the latest scientific and medical periodicals, the high school chemistry teacher, the indexers and abstractors at scientific publishing firms, the graduate student who asks a question 


\section{4,000 ways to make a difference:}

\section{- To Patrons:}

New Products to Support On-line PACs put patrons in touch with information faster and easier than ever.

Handicapped-Access innovations help you comply with the new "Americans with Disabilities Act."

Unique Merchandising and Signage products get your collection out where the public can see and enjoy it.

\section{- To Staff:}

Make Everyday Jobs Faster, Easier, More Rewarding with products that save time, money, and floor space.

A Totally New Catalog Design with an expanded, annotated index for easier reference, plus more detailed, complete product information and hundreds of new, full-color photos.

\section{- To Your Budget:}

More Quantity Discounts to help your library save money in these troubled economic times.

Gaylord Quality that lasts - because products you only buy once save you money.

\section{To the \\ Environment:}

Recycled Paper used to print this reference catalog saved 3,570 trees, $861,000 \mathrm{kWs}$ of electricity, and almost 1.5 million gallons of water, while eliminating 12,600 pounds of pollutants and 11,340 cubic feet of waste.

If you haven't yet received your copy of Gaylord's new 1992 Catalog, a toll-free call can make all the difference.

-1-800-448-6160

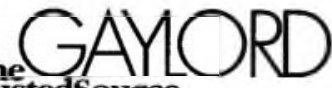

24,000 products, including over 400 brand-new ones. 
about biosensors at the reference desk, the editorial assistant between assignments at a scientific publishing house, and the secretary with a degree in zoology who loves to read. If one of them knows you are a science librarian, they might approach you and ask what is involved in becoming a librarian. Tell them how they might be well suited to this area of librarianship because of their familiarity with libraries or the information industry and their inherent interest in the sciences.

\section{Conclusion}

Sharing information and practical tips about recruiting might be the most important strategy of all. The "Each One Reach One" concept mentioned previously would be extremely potent if many of us put it into practice. Institutions should develop models and practices based on those that are mentioned in the literature or discussed at conferences: plans for how library schools can keep a high profile within their institutions and for how librarians can help dispel stereotypes about the profession ${ }^{10}$; brochures outlining employment opportunities in science by geographical region ${ }^{11}$, and even more ambitious long-range plans, such as library schools implementing joint degrees with scientific or technological disciplines. Sci-tech librarians have a responsibility to take the lead in some of the ways described here.

Those of us who do not have science backgrounds need to be aware of opportunities in science libraries for ourselves (job rotation, in-service training) and for others. Scan the job listings for science librarians, know the names of science librarians at nearby universities and special libranies so you can always get additional information for a potential recruit. If you came to librarianship from another field, do your former colleagues know what you're doing now? Be available to those who might be interested in a career change. You already speak their language - speak to them about librarianship! Last but not least, being a science librarian is fun.

You can get great satisfaction from knowing that when desperate graduate students come looking for dictionaries to help them with their language exams, you can actually produce one that covers high energy physics in English, French, Russian, and German. Or knowing how to locate a technical report from NASA or a patent application from Japan for a new technology because the director for R\&D at your corporation needs it for the coming year's R\&D plan. Most satisfying of all is helping out the undergrads who have never before set foot in a university science library; showing them the array of subjects covered by the indexes and how to find all sorts of needed information about their paper topics. The best thing they can say by way of thanks is "Wow, I never knew stuff like this existed!"

\section{NOTES}

'L. Brown, "Recruiting science librarians," in Librarians for the New Millennium, W. Moen and K. Heim, eds. (Chicago: American Library Association, 1988), pp. 65-71.

${ }^{2}$ W. Moen and K. Heim, "The class of 1988 : Librarians for the new millennium," American $\mathrm{Li}$ braries (November 1988): 858-61.

${ }^{3}$ Richard C. Pearson and T. D. Webb, "The new librarians: How prepared are they?" Library Journal (September 1, 1988): 132-34.

${ }^{1}$ Ibid., p. 133.

${ }^{5}$ Office of Library Personnel Resources, American Library Association, personal communication.

${ }^{6}$ Brown, "Recruiting science librarians," p. 65.

${ }^{7}$ Moen and Heim, "The class of 1988: Librarians for the new millenium," p. 860.

${ }^{8}$ Pearson and Webb, "The new librarians: How prepared are they?" p. 133.

${ }^{9}$ Ibid.

${ }^{10} \mathrm{~B}$. Dewey, "Selection of librarianship as a career: Implications for recruitment," Journal of Education for Library and Information Science 26 (Summer 1985): 16-24.

${ }^{11}$ Brown, "Recruiting science librarians," p. 68.

\section{Preparing to be a science librarian in college}

As an undergraduate with a biology major, I assumed that all librarians had humanities or English literature backgrounds. Until an academic librarian told me that having a science degree would be extremely valuable in a career in the library field, it had never occurred to me to become a librarian. The zoology course at my undergraduate institution required students to survey and review the literature on a selected animal species in a comprehensive term paper. I had always been interested in libraries, so I spoke with my advisor in the biology department and with a reference librarian, and was able to get approval for an individual study course.

The librarian introduced me to the various collections in the library and to basic bibliographic resources such as Sheehy's Guide to Reference Books. She also assigned selected readings in the library literature and had me observe online searches. My final project was to develop a pathfinder for the biotechnology literature, which later became part of the library's series of pathfinders. This early exposure to the field of librarianship was the determining factor in my decision to become a science librarian.-CCW 